\title{
DETERMINANT FACTORS ASSOCIATED WITH PATIENT SAFETY CULTURE IN DHARMA YADNYA GENERAL HOSPITAL BALI
}

\author{
Putu Darmika, Ede Surya Darmawan \\ Study Program of Hospital Administration \\ Faculty of Public Health University Indonesia
}

\begin{abstract}
Patient safety is a global issue where the achievement is low, so that it needs to implement a patient safety culture. The patient safety culture is measured based on 12 elements of the patient's safety culture according to $A H R Q$ and the application of 6 patient safety goals. Perceived causes of the problem is the work environment, team work, leadership, job satisfaction and job stress. At RSU Dharma Yadnya Denpasar, the staff's perception about patient safety culture is not known yet, but the incident rate is still high. The purpose of this research is to know the correlation of determinant of factor which is related to patient safety culture.

This research used cross sectional design which analyzed by Partial Least Squares (PLS), with sample of nurses and midwife implementer which is 72 respondents. The results of this study indicate that there is a significant correlation between work team, leadership, and work stress with the patient safety culture, respectively 3.707, 12.647, and 3.135> T Statistics 1.96. While there is no significant correlation between work environment and job satisfaction with patient safety culture equal to 1,336 and 0,328 <T Statistic 1,96. This study concludes that teamwork, decreased levels of work stress and the application of transformational leadership models need to be applied in an effort to improve the patient safety culture in the hospital.
\end{abstract}

Keywords: determinants factors, patient safety culture, work environment, team work, leadership, job satisfaction, stress work.

\section{FAKTOR DETERMINAN YANG BERHUBUNGAN DENGAN BUDAYA KESELAMATAN PASIEN DI RUMAH SAKIT UMUM DHARMA YADNYA BALI}

\begin{abstract}
ABSTRAK
Keselamatan pasien adalah masalah global dimana pencapaiannya masih rendah, sehingga perlu diterapkan budaya keselamatan pasien. Budaya keselamatan pasien diukur berdasarkan 12 elemen budaya keselamatan pasien berdasarkan AHRQ dan penerapan dari 6 tujuan keselamatan pasien. Penyebab masalah ini adalah lingkungan kerja, kerja tim, kepemimpinan, kepuasan kerja dan stres kerja. Di RSU Dharma Yadnya Denpasar, persepsi staf tentang budaya keselamatan pasien belum diketahui, tetapi tingkat insiden masih tinggi. Tujuan dari penelitian ini adalah untuk mengetahui faktor yang berhubungan dengan budaya keselamatan pasien. Penelitian ini menggunakan desain cross sectional yang dianalisis dengan Partial Least Squares (PLS), dengan sampel perawat dan pelaksana bidan yang berjumlah 72 responden. Hasil penelitian ini menunjukkan bahwa ada korelasi yang signifikan antara tim kerja, kepemimpinan, dan stres kerja dengan budaya keselamatan pasien, masingmasing $3,707,12,647$, dan 3,135> T Statistik 1,96. namun tidak ada hubungan yang signifikan antara lingkungan kerja dan kepuasan kerja dengan budaya keselamatan pasien sebesar 1,336 dan 0,328<T Statistik 1,96. Penelitian ini menyimpulkan bahwa kerja tim, penurunan tingkat stres kerja dan penerapan model kepemimpinan transformasional perlu diterapkan dalam upaya meningkatkan budaya keselamatan pasien di rumah sakit.
\end{abstract}

Kata kunci: Faktor penentu, budaya keselamatan pasien, lingkungan kerja, kerja tim, kepemimpinan, kepuasan kerja, stres kerja 


\section{BACKGROUND}

Patient hospital safety will be achieved if all hospital staff are able to implement a patient safety culture. Patient safety conditions will be well established if there is an effective safety system to protect both patients and all health workers within the scope of the organization, protecting health workers from patient demands when medical errors occurs. ${ }^{1}$ Nationally low application of patient safety culture can be seen from various research results conducted in several hospitals in Indonesia. Based on ${ }^{2}$ study found that $65.9 \%$ (58 people) of nurses still had poor safety culture. Research on Bali about patient safety culture has not been done. The research conducted by Rasdini, $^{3}$ on the correlation of the application of patient safety culture to the supervision of nursing service by the implementing nurse at Sanglah Denpasar Hospital.

The safety culture of patients depicted in the Dharma Yadnya Denpasar-Bali hospital is the patient's safety team or other staff will just make efforts to anticipate or think about the patient's safety culture if there is only a patient safety issue. Based on this it can be said that the factors of job satisfaction, work environment, teamwork, job stress and leadership contribute to the implementation of patient safety culture in the hospital. Besides that there is a close relationship relationship between work environment with job satisfaction, work stress, team work and leadership style and vice versa. Therefore, researchers feel the need to examine the determinants of factors associate to patient safety culture at RSH Dharma Yadnya Denpasar-Bali, to meet the public demand for quality and quality of care for patient safety.

\section{METHODS}

This research using cross sectional design. The sample used in this research is all Nurse and Midwife executor who work in RSU Dharma Yadnya Denpasar-Bali, amounted to 72 respondents. All data that have been collected in subsequent research is processed by using computer-based statistic SPSS and PLS (Partial Least Squere). PLS is used in this study because it does not assume data with a certain scale measurement and can be used on a limited sample. ${ }^{4}$

\section{RESULT \\ Respondent's Characteristic}

Characteristics of respondents in this study gives a picture of the distribution of respondents who amounted to 72 people. Details of the frequency distribution of respondents as shown in table 1 as follows 
Table1.

Frequency Distribution of Respondent Characteristics $(n=72)$

\begin{tabular}{|c|c|c|c|}
\hline $\begin{array}{c}\text { Demographic } \\
\text { Characteristics } \\
\end{array}$ & Category & Frequency & Percentage \\
\hline \multirow{2}{*}{ Gender } & Man & 20 & 27.78 \\
\hline & Women & 52 & 72.22 \\
\hline \multirow{4}{*}{ Age } & $15-24$ years & 19 & 26.39 \\
\hline & $25-34$ years & 40 & 55.55 \\
\hline & $35-44$ years & 12 & 16.67 \\
\hline & $45-54$ years & 1 & 1.39 \\
\hline \multirow{3}{*}{ Education } & D3 Nursing & 46 & 63.89 \\
\hline & D3 Midwifery & 14 & 19.44 \\
\hline & $\begin{array}{l}\text { S1 Nursing, } \\
\text { Profesion }\end{array}$ & 12 & 16.67 \\
\hline \multirow{5}{*}{ Work Experience } & $0-4$ years & 39 & 54.17 \\
\hline & $>4-8$ years & 16 & 22.22 \\
\hline & $>8-12$ years & 7 & 9.72 \\
\hline & $>12-16$ years & 3 & 4.17 \\
\hline & $>16-20$ years & 7 & 9.72 \\
\hline \multirow{3}{*}{ Marital status } & Sigle & 33 & 45.83 \\
\hline & Married & 39 & 54.16 \\
\hline & RI Barata & 16 & 22.22 \\
\hline \multirow{6}{*}{ Work unit } & $\begin{array}{l}\text { RI Ayodya, } \\
\text { VK \& Bayi }\end{array}$ & 19 & 26.39 \\
\hline & OK \& CSSD & 11 & 15.27 \\
\hline & IGD & 11 & 15.27 \\
\hline & ICU & 8 & 11.11 \\
\hline & Poliklinik & 1 & 1.38 \\
\hline & HD & 6 & 8.33 \\
\hline
\end{tabular}

Based on table 1 above shows that the majority of respondents female sex is 52 people (72.22\%), the majority of respondents aged 25 34 years, as many as 40 people $(55.55 \%)$, the majority of respondents educated D3 Nursing, which is 46 People (63.89\%), the majority of respondents have a working period of 0-4 years, as many as 39 people $(54.17 \%)$, the majority of respondents have been married, as many as 39 people $(54.17 \%)$, and respondents in the unit of Inpatient Ayodia, VK and Baby Room, which is 19 people $(26,39 \%)$.

\section{Frequency Distribution of Research Variables}

Table2.

Frequency Distribution of Variabel Work Environment, Team Work, Leadership, Job Satisfaction \& Stress Work

\begin{tabular}{|c|c|c|c|c|c|c|c|}
\hline \multirow{3}{*}{ Kode } & \multirow{3}{*}{ Variable/indicator } & \multicolumn{6}{|c|}{ Respondent's Perception Response Criteria $(n=72)$} \\
\hline & & \multicolumn{2}{|c|}{ Not Good } & \multicolumn{2}{|c|}{ Passable } & \multicolumn{2}{|c|}{ Good } \\
\hline & & $\mathbf{f}$ & $\%$ & $\mathbf{f}$ & $\%$ & $\mathbf{f}$ & $\%$ \\
\hline $\mathrm{X} 1$ & Work environment & 1 & 1.4 & 31 & 43.1 & 40 & 55.6 \\
\hline $\mathrm{X} 2$ & Team work & 0 & 0.0 & 21 & 29.2 & 51 & 70.8 \\
\hline $\mathrm{X} 3$ & Leadership & 10 & 13.9 & 39 & 54.2 & 23 & 31.9 \\
\hline $\mathrm{X} 4$ & Job satisfaction & 0 & 0.0 & 21 & 29.2 & 51 & 70.8 \\
\hline $\mathrm{X} 5$ & Stress work & 0 & 0.0 & 44 & 61.1 & 28 & 38.9 \\
\hline
\end{tabular}


Based on table 2 it can be explained that most of the respondents are as many as 40 people $(55.6 \%)$ stated good working environment, 51 people $(70,8 \%)$ expressed support good working team, as many as 39 people $(54,2 \%)$ stated model leadership is good enough, most of respondents are 51 people (70,8\%) expressed satisfaction, and most of respondents stated enough stress in their work that is as many as 44 people $(61,1 \%)$.

Table 3.

Frequency Distribution of Patient Safety Culture Variables

\begin{tabular}{|c|c|c|c|c|c|c|c|}
\hline \multirow[t]{3}{*}{ Code } & \multirow{3}{*}{ Variabel/Indicator } & \multicolumn{6}{|c|}{$\begin{array}{l}\text { Respondent's Perception Response Criteria } \\
(\mathrm{n}=72)\end{array}$} \\
\hline & & \multicolumn{2}{|c|}{ Not Good } & \multicolumn{2}{|c|}{ Passable } & \multicolumn{2}{|c|}{ Good } \\
\hline & & $\mathbf{f}$ & $\%$ & $\mathbf{f}$ & $\%$ & $\mathbf{f}$ & $\%$ \\
\hline $\mathrm{Y}$ & Pateint Safety Culture & 4 & 5.6 & 32 & 44.4 & 36 & 50.0 \\
\hline y1 & Frequency of reporting & 0 & 0.0 & 10 & 13.9 & 62 & 86.1 \\
\hline $\mathrm{y} 2$ & Staff perception & 13 & 18.1 & 25 & 34.7 & 34 & 47.2 \\
\hline y3 & Supervision & 9 & 12.5 & 28 & 38.9 & 35 & 48.6 \\
\hline y4 & Organizational learning & 3 & 4.2 & 16 & 22.2 & 53 & 73.6 \\
\hline y5 & Team work unit & 2 & 2.8 & 17 & 23.6 & 53 & 73.6 \\
\hline y6 & Openness of communication & 1 & 1.4 & 20 & 27.8 & 51 & 70.8 \\
\hline y7 & Feedback & 6 & 8.3 & 19 & 26.4 & 47 & 65.3 \\
\hline y8 & not to blame Response & 8 & 11.1 & 62 & 86.1 & 2 & 2.8 \\
\hline y9 & Staffing & 3 & 4.2 & 11 & 15.3 & 58 & 80.6 \\
\hline y10 & Management support & 6 & 8.3 & 37 & 51.4 & 29 & 40.3 \\
\hline y11 & Team work between units & 2 & 2.8 & 40 & 55.6 & 30 & 41.7 \\
\hline y12 & Hands off and transition & 13 & 18.1 & 8 & 11.1 & 51 & 70.8 \\
\hline y13 & Patient identification & 26 & 36.1 & 30 & 41.7 & 16 & 22.2 \\
\hline y14 & Effective communication & 13 & 18.1 & 32 & 44.4 & 27 & 37.5 \\
\hline y15 & Drug high alert & 10 & 13.9 & 36 & 50.0 & 26 & 36.1 \\
\hline y16 & Surgical safety & 8 & 11.1 & 27 & 37.5 & 37 & 51.4 \\
\hline y17 & Prevention of infection & 9 & 12.5 & 28 & 38.9 & 35 & 48.6 \\
\hline y18 & Prevents the risk of falling & 9 & 12.5 & 26 & 36.1 & 37 & 51.4 \\
\hline
\end{tabular}

Based on table 3 above can be explained that some respondents that as many as 36 people $(50.0 \%)$ have a good patient safety culture and only 4 respondents $(5.6 \%)$ have a poor patient safety culture. Based on each indicator seen that most respondents have good reporting culture that is as much as 62 respondents $(86,1 \%)$. There are 26 respondents $(36,1 \%)$ have poor patient safety culture that is on patient identification indicator. 


\section{Modeling Factors Related to Patient Safety Culture}

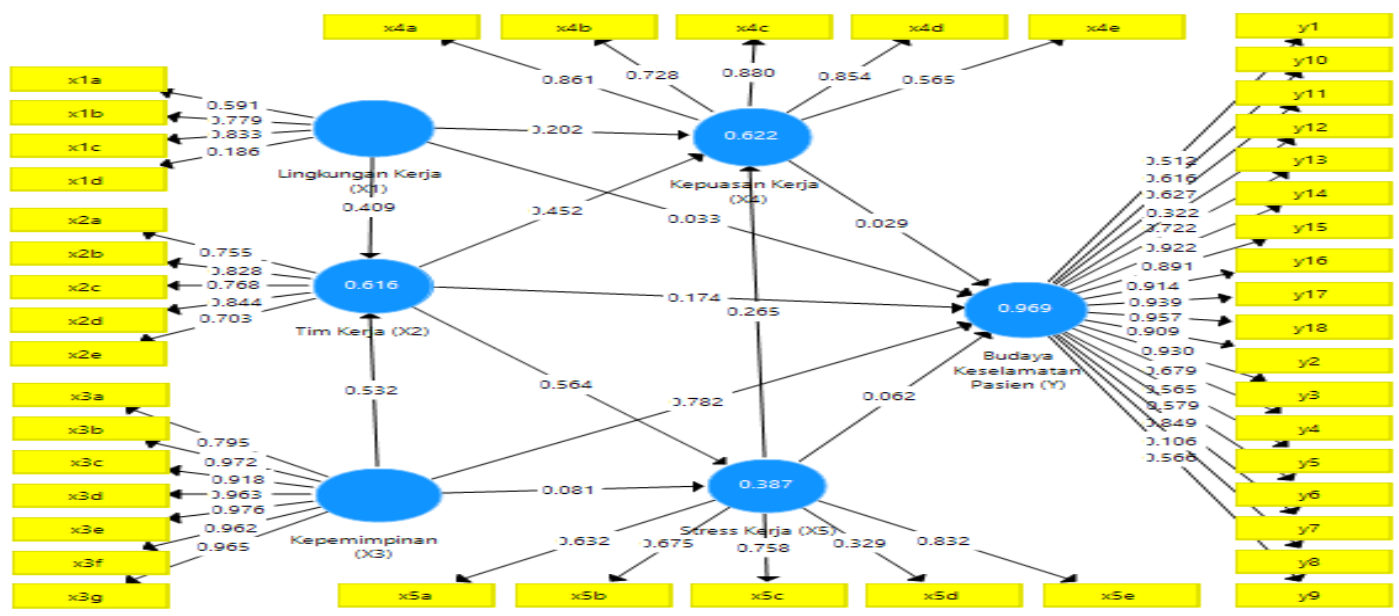

Figure 1.

Output SmartPLS 3.0 Untuk Evaluasi Outer Model (Algoritm)

Based on the outer loading above, it is known that there are four indicators that have a loading below 0.5 so it can not be tolerated and must be eliminated, ie voice indicator (x1d), role demands (x5d), blame response (y8), and
Hands off and transition (y12). Furthermore, realgorithm analysis is performed after eliminating the indicators that do not meet the standard, so that the output as shown in Figure 2, as follows:

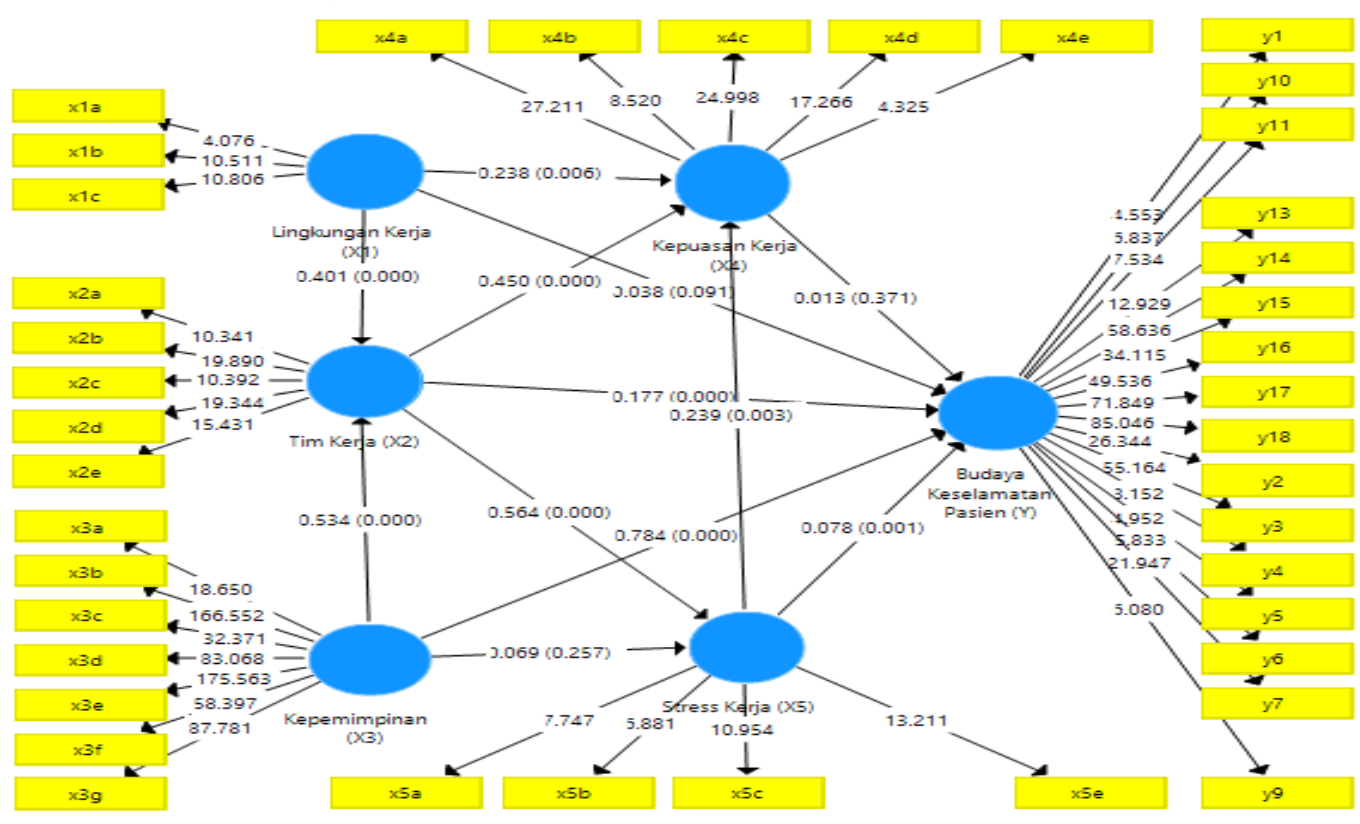

Figure 2.

Output SmartPLS 3.0 for Evaluation of Outer Model after Eliminir (Algorithm) 
After done eleminir on outer model so that fulfillment of requirement analysis, then got correlation between variable as follows:

Tabel 4.

Path Coefficient (Mean, STDEV, T Values)

\begin{tabular}{lccccc}
\hline & $\begin{array}{c}\text { Original } \\
\text { Sample (O) }\end{array}$ & $\begin{array}{c}\text { Sample } \\
\text { Mean (M) }\end{array}$ & $\begin{array}{c}\text { Standard } \\
\text { Deviation } \\
(\text { STDEV) }\end{array}$ & $\begin{array}{c}\text { T Statistics } \\
(\mid \mathbf{O} / \text { STDEV })\end{array}$ & P Values \\
\hline Work environment -> Team work & 0.401 & 0.405 & 0.095 & 4.244 & 0.000 \\
Work environment -> Job satisfaction & 0.238 & 0.245 & 0.095 & 2.511 & 0.006 \\
Work environment -> Culture Kaiser & 0.038 & 0.033 & 0.028 & 1.336 & 0.091 \\
Permanente (KP) & 0.45 & 0.445 & 0.083 & 5.424 & 0.000 \\
Team work -> Job satisfaction & 0.564 & 0.569 & 0.102 & 5.514 & 0.000 \\
Team work -> Stress work & 0.177 & 0.182 & 0.048 & 3.707 & 0.000 \\
Teamwork -> Culture KP & 0.534 & 0.532 & 0.069 & 7.693 & 0.000 \\
Leadership -> Teamwork & 0.069 & 0.085 & 0.106 & 0.654 & 0.257 \\
Leadership-> Stress work & 0.784 & 0.778 & 0.062 & 12.647 & 0.000 \\
Leadership -> Culture KP & 0.013 & 0.017 & 0.041 & 0.328 & 0.371 \\
Job Satisfaction -> Culture KP & 0.239 & 0.24 & 0.086 & 2.764 & 0.003 \\
Stress work -> Job satisfaction & 0.078 & 0.073 & 0.025 & 3.135 & 0.001 \\
Stress work -> Culture KP & & & & & \\
\hline
\end{tabular}

In table 4 above can be explained that there is no significant relationship between work environment and work satisfaction with patient safety culture in a row of 1.336 and $0.328<\mathrm{T}$ Statistik 1.96. there is a significant correlation between work team, leadership and work stress with patient safety culture as big as 3,707, 12,647, and 2,764> T Statistic 1.96.

\section{DISCUSSION}

From the result of this research: (1) there is no significant correlation between work environment and patient safety culture; (2) there is significant correlation between work team with patient safety culture; (3) there is significant between leadership and patient safety culture; (4) there is no significant relation between job satisfaction with patient safety culture; and (5) there is significant correlation between work stress with patient safety culture.
There is no significant correlation between working environment / working condition and patient safety culture in this research, same as previous study by Rasdini et $\mathrm{al}^{3}$ where the results of the correlation between this determinant factors affecting patient safety culture are $p$ values $0,507>0.05$, which means that the working conditions are not related to the patient's safety culture. The safety culture of the patient is significantly related to the work team. The results of this study are supported and in accordance with what was submitted by Rachmawati ${ }^{5}$ that teamwork has a positive and significant relationship with the patient safety culture.

The result of the analysis on the relationship of leadership with the safety culture of the patients obtained the result that there is a significant relationship. The results of this study are in accordance with a statement submitted by Anwar, ${ }^{6}$ that Leadership is the most important 
thing in creating a patient safety culture. Leaders who always pay attention to patient safety is a leader who is very concerned about the quality and quality of service, so that this safety culture should start from the leader itself.

The safety culture of the patients in this study showed that the results did not correlate significantly with job satisfaction. The results of this study contradict what is presented by Geller in, ${ }^{7}$ that job satisfaction which is part of organizational behavior factor related to patient safety culture. This is in accordance to other research, ${ }^{8}$ that patient safety culture is a shared perception among members of the organization aimed at protecting patients from mismanagement or injury due to intervention tinjauan teoritis.

The safety culture of patients in this study is significantly related to work stress. The problem of work stress is a problem that is often faced by everyone in working life. In other words that if the means and task demands are not in harmony with the needs and abilities of a person then he will experience stress. ${ }^{9}$ This is in accordance to the assertion, ${ }^{5}$ that individual factors and officers are very influential on the application of patient safety culture. The individual factors that are strongly associated in this case is the level of stress in the work.

\section{REFERENCES}

1. Sulistiani. Korelasi Budaya Keselamatan Pasien dengan Persepsi Pelaporan Kesalahan Medis oleh Tenaga Kesehatan Sebagai Upaya Peningkatan Keselamatan Ddan Kesehatan Kerja di Rumah Sakit X dan Rumah Sakit Y Tahun 2015 [skripsi]. Jakarta: Fakultas Kedokteran dan Ilmu Kesehatan Universitas Islam Negeri Syarif Hidayatullah; 2015.

2. Mulyati, Lia. Faktor Determinan yang Memengaruhi Budaya Keselamatan Pasien

\section{CONCLUSIONS}

The results of this study conclude that: There is a significant correlation between work team, leadership and work stress with patient safety culture on nurses and midwives in public hospital Dharma Yadnya Denpasar-Bali. There is no significant correlation between work environment and patient safety culture, there is no significant correlation between leadership with job stress, and there is no significant correlation between job satisfaction with patient safety culture on nurse and midwife in public hospital Dharma Yadnya Denpasar- Bali.

Based on the findings and conclusions submitted by the researcher, in this case can be advised to be done both short and long term so that the safety of patients can be improved kesdaannya in RSU Dharma Yadnya Denpasar. The suggestions are: to maintain and even improve the perceived work environment by nurses and midwives in their work, to support the work team so that indirectly support the application of patient safety culture, seeing the results of effective research on the transformational leadership model, the structural model in this study is fit and is said to have a relatively good predictive value, it is expected that the next researcher can confirm the research using this research model, or use other variables that have not been used in this research.

di RS Pemerintah Kuningan [tesis]. Jawa Barat: STIKes Kuningan; 2016.

3. Rasdini IA, Wedri NM, Mega I. Hubungan Penerapan Budaya Keselamatan Pasien dengan Supervisi Pelayanan Keperawatan oleh Perawat Pelaksana di RSUP Sanglah Denpasar Tahun 2014 [cited 26 September 2017]. Available from http://poltekkesdenpasar.ac.id/files/jurnal\%20gema\%20ke perawatan/desember\%202014/artikel\%20ig a\%20ari\%20rasdini\%20dkk,.pdf 
4. Ghozali. Structural Equation Modeling Metode Alternatif dengan Partial Least Squere (PLS); Edisi Ketiga. Semarang: Universitas Diponegoro; 2011.

5. Rachmawati. Model Pengukuran Budaya Keselamatan Pasien di RS Muhammaddyah-Aisyaiah tahun 2011 [disertasi]. Depok: Fakultas Kesehatan Masyarakat Universitas Indonesia; 2011.

6. Anwar. Hubungan Fungsi Manajemen Kepala Ruang dengan Penerapan Patient Safety Culture di Rumah Sakit Umum DR. Zainoel Abidin Banda Aceh [tesis]. Medan: Universitas Sumatera Utara; 2016.

7. Chooper. Towards a Model of Safety Culture. Safety Science. 2000;32(6), 111136

8. Beginta, R. Pengaruh Budaya Keselamatan Pasien, Gaya Kepemimpinan, Tim Kerja, terhadap Persepsi Pelaporan Kesalahan Pelayanan oleh Perawat di Unit Rawat Inap Rumah Sakit Umum Daerah Kabupaten Bekasi Tahun 2011 [tesis]. Depok: Universitas Indonesia; 2012

9. Siagian. Manajemen Sumber Daya Manusia, Cet Ke-19. Jakarta: Bumi Aksara; 2011. 